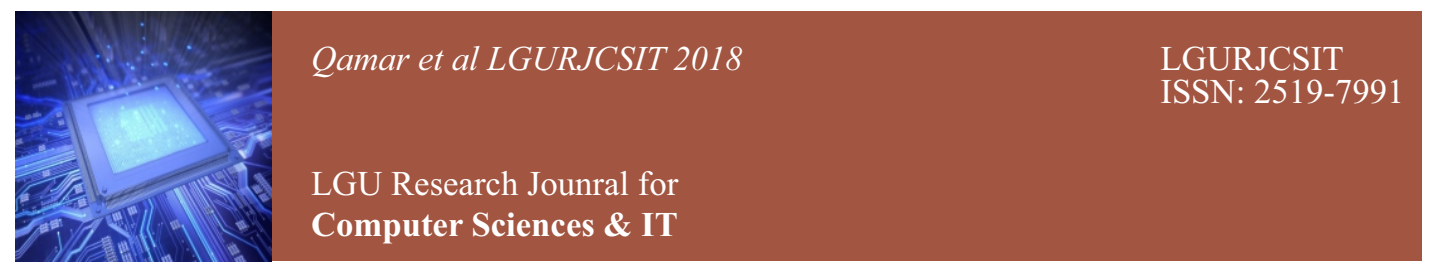

\title{
The Work Life Challenges Faced by Women in Our Society
}

Mehreen Qamar

Kinnaird College for Women University, Jail Road, Lahore, Pakistan

Corresponding author: qamarmehreen@gmail.com

\section{Abstract}

Men and women should possess same status as they are the most important pillar of any society; without their equivalent involvement in every sphere of life, no civilization can progress. As far as the abilities of women are concerned, they should not be considered any lesser than men. The women of our age are fulfilling their role as doctors, teachers, lawyers, and a number of other grounds of life but still society has not provided them the equitable position that they so rightfully deserve. The part of working women has transformed all over the world due to many socio-economic conditions. They are disregarded when it comes to making decision and are not encouraged to higher posts in offices even if they deserve to be. The natural belief that women are not capable of performing strenuous work or are less resourceful than men rules this prejudice of unsatisfactory salary packages for working on the same job. Some difficulties are certainly common, like mental and physical health, imbalance between family life and employment, unfair behavior towards women in the working place and work place perception regarding women's character etc. Thus, accomplishing balance in working life is essential for women who are working in order to have a good quality of life. Nonetheless government authorities and parents are reassuring the females to work and play a dynamic character in the growth of the society. Although the atmosphere and working environments are the least fortunate for those who challenge to come out of the four walls of the safe haven yet the women had to start somewhere. This article describes the effort to discover the unpleasant challenges tackled by working women in sustaining equilibrium between their individual and professional life.

\section{Keywords}

Work-life balance, quality of life, working women, personal life, professional life.

\section{INTRODUCTION}

Women belonging to the early times were customarily confined to their homes working in their kitchens and those who were educated worked in factories, farms or shop works. A hand full of women had the luxury to get higher education. Most of them were forced to be at the mercy of their father's or husband's when it comes to education. The cost of living has tremendously risen; cumulative overheads on education of children, growing cost for house possessions force each and every family in our country to overlook for ways and means to increase the domestic income. As a consequence, women who were typically thought of as homemakers are involuntary asked to perform jobs with their husbands. When working women get married, they have added household tasks and when they turn into mothers, they have to manage their newly extended family and are thus, under bigger pressure to stay on the chosen career. Women working anywhere face a lot more challenging situations than their peers. The effort of working women to incorporate, consolidate and bring stability to the numerous problems and undertakings in their diverse roles at the same time puts them under tremendous pressure. [1]

Problems concerning their health are expected to lead to lesser throughput and value of worker herself. In Pakistan working women face most of glitches that are not faced by the working women in advanced countries. In Pakistan mostly men don't share household chores. It is the primary responsibility of women 
to make food, to take care of her children and family and perform various house chores. Therefore major burden lies on shoulders of women. In spite of all constraints, Pakistani women are conscious of their demand of work and they are motivated to work for themselves, their families and their country [2].This paper laid emphases on the harsh life of women working in various field; in their fight to work out steadiness between their work and domestication.

\subsection{Research Problem}

This enquiry predominantly emphases on challenges and risks confronted by female workers working in different organizations and the difficulties they handled on the basis of gender discernment. Women constitute more than half the population of our country. Their assistance to the regions well-being nevertheless, remained underestimated and essentially unseen, and their requirements and ambitions habitually lingered as unrecognized.

\subsection{Research Objectives}

The foremost emphasis of this research study is to examine the complications of officially employed women in diverse sectors in the Lahore region of Pakistan. $\quad \mathrm{S} \quad \mathrm{u} \quad \mathrm{b}$ objectives comprise:

- $\quad$ To find out home related complications of legally employed women in the areas under focus.

- To determine behavior of family associates and social circle of an employed women to their job in focus area.

\subsection{Significance of the study}

The research in this region encompasses the knowledge base that at present exists in this arena. This subject has qualified significance in research field as very little effort is done on complications of working women in Pakistan and no research study is approved to observe the working difficulties of officially employed women in Lahore, the area under emphasis. This research is tremendously noteworthy as women are as significant in the social order as men, so study like this pinnacle the glitches of working women in diverse divisions in Lahore in precise and the country and the world in broad which in turn help to diminish those problems.

\section{LITERATURE REVIEW}

Literature review is the foundation of any research. Quality research cannot be conceivable if it is devoid of reviewing literature expansively because it aids us to find out research gap in prevailing body of knowledge.

In certain sectors, women are occupied as inexpensive labor and are compensated fewer wages than their male equivalents. Females "workplace, too, is not often adequately designed where they could feel at ease during work and break timings". Such ill-disposed and domineering behavior of employers is not a distinctiveness of our society; rather it is a world known problem, and descendant of the capitalistic methodology, in which the real objective of any financier is revenue expansion, and not human well-being [3].

Jahan (1975) claimed that women are invisible and un-organized, they cannot precisely define their complications consequently they miss the mark to draw the consideration of researchers. But now circumstances have changed steadily. The contribution of women in labor market has slowly but surely increased in the course of the mid of 1980's [4].

Even during the work or work place they are treated as a lesser being for not coming up to the level of their male equivalents. Their male contemporaries don't back them; they are reminded quite often that they do not have ample skills to do the required work at hand. Their colleague and minions feel that they have no assessment power and are unable to make dogmas. They have the restrictions of not staying in late hours or during off days; therefore they are well-thought-out to be unfit in majority of the cases [2].

Getzels and Guba (1954) initiated that out of three characters of wife, mother and employee, a woman inhabiting parts of wife and employee will encounter more conflict than a women inhabiting the part of wife and mother because of the greater discordance amongst the roles. Furthermore, the battle of woman will be all the more powerful if her employer, her husband as well as household members held irrational hopes from her. This indicates that women who decide on to combine marriage with occupation face a precarious situation and they barely know how to allocate time and resources among these two major account abilities. This makes them encounter great struggle, pressure and anxiety [5]. 
In a latest seminar on "women's employment concerns and working conditions organized by the employers" Federation of Pakistan (EFP), Sindh Governor, Muhammad Soomro self-proclaimed the datum that incorporation of women in the advancement procedure as equal partners, has developed as one of the key zones of governments strategies not only for us at this point in Pakistan, but at the universal level as well. Significance devoted to women's matters and principally those associated to their employment and human resource expansion are acknowledged as fundamental to the growth of any country [6].

\section{FRAMEWORKAND METHODOLOGY}

The women working as teachers, doctors, engineers and other departments in Lahore.

The context of the study gives a schematic illustration of the research in order to contribute an improved level of understanding of the problem.

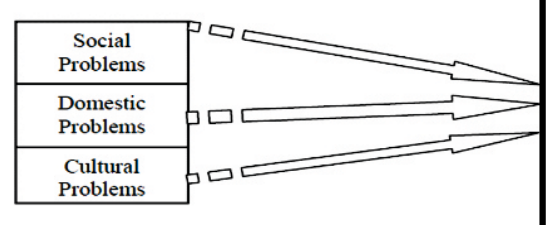

The women working as teachers, doctors, engineers and other departments in Lahore.

\subsection{Description of Sample}

A survey was directed amongst the women working in Lahore. A small sample of 151 working women was carefully chosen. Women included in the survey were from Academic, IT and other sectors. Age group was carefully chosen to be 25 years and above. Google Docs was used for the data assemblage. Online questionnaire was circulated through social networks, through email, through universities portals and through different mediums. Analysis was performed by applying statistical hypothesis and presented with the help of MATLAB grounded on the survey data.

The specifics of few declarations to get a better transparency in the study on "work life balance" in the married working women of Lahore are mentioned: details regarding the demographic particulars of the respondents namely the age category, number of family members, marital status and Profession the respondent is working in. A few questions encompassed are the reason behind choosing the career field, difficulty to look after family members due to work, causes of low promotion of women and health issues faced by the women of our society.

\subsection{Data Collection}

The questionnaire was distributed to the women working in various sectors in person as well. A total of 75 were distributed by hand and 76 were filled online. 151 completely filled questionnaires were collected at the end.

\subsection{Scope}

The scope of our survey was narrowed down to the working women of Lahore from the educational, health and IT sectors on the subject of the challenges that they face in balancing "professional life and personal life." 
Table 1: Demographic Characteristics of Respondents (working women)

\begin{tabular}{|c|c|c|}
\hline $\begin{array}{c}\text { "Demographic Characteristics of } \\
\text { Respondents" }\end{array}$ & "Frequency" & "Percentage \%" \\
\hline \multicolumn{3}{|l|}{ Age Group of Respondents: } \\
\hline Below 25 & 86 & 57 \\
\hline 26 to 30 & 43 & 28.5 \\
\hline 31 to 35 & 13 & 8.6 \\
\hline 36 to 40 & 5 & 3.3 \\
\hline Above 40 & 4 & 2.6 \\
\hline TOTAL & 151 & 100 \\
\hline \multicolumn{3}{|l|}{ Number of family members: } \\
\hline Below 5 & 63 & 41.7 \\
\hline Above 5 & 88 & 58.3 \\
\hline TOTAL & 151 & 100 \\
\hline \multicolumn{3}{|l|}{ Marital status: } \\
\hline Married & 47 & 31.5 \\
\hline Unmarried & 102 & 68.5 \\
\hline TOTAL & 149 & 100 \\
\hline \multicolumn{3}{|l|}{ Profession: } \\
\hline Teacher & 62 & 41.1 \\
\hline Banker & 3 & 2 \\
\hline Doctor & 10 & 6.6 \\
\hline Engineer & 18 & 11.9 \\
\hline Business Women & 11 & 7.3 \\
\hline Other & 47 & 31.1 \\
\hline TOTAL & 151 & 100 \\
\hline
\end{tabular}

\subsection{Mean and Standard Deviation}

The mean and standard deviation of responses for each question are tabulated as below: 
Table 2: Mean and Standard deviation of Respondents (working women)

\begin{tabular}{|c|c|c|c|c|c|}
\hline Statements & Frequency & $\begin{array}{l}\text { Percentage } \\
\%\end{array}$ & $\mathbf{N}$ & Mean & S.D \\
\hline $\begin{array}{l}\text { Your job experience in years? } \\
1 \text { to } 5 \\
6 \text { to } 10 \\
11 \text { to } 15 \\
16 \text { to } 20 \\
\text { Above } 20\end{array}$ & $\begin{array}{c}129 \\
15 \\
4 \\
1 \\
1\end{array}$ & $\begin{array}{l}86 \\
10 \\
2.7 \\
0.7 \\
0.7\end{array}$ & 150 & 3.974 & 2.877 \\
\hline $\begin{array}{l}\text { What is your income? } \\
\text { Less than } 35000 \\
\text { Between } 35000 \text { to } 50000 \\
\text { Between } 50000 \text { to } 75000 \\
\text { Above } 75000\end{array}$ & $\begin{array}{c}86 \\
35 \\
20 \\
7\end{array}$ & $\begin{array}{c}58.1 \\
23.6 \\
13.5 \\
4.7\end{array}$ & 148 & 37615.9 & 15466.7 \\
\hline $\begin{array}{l}\text { How many hours do you work in a day? } \\
\text { Less than } 8 \\
\text { More than } 8\end{array}$ & $\begin{array}{l}91 \\
59 \\
\end{array}$ & $\begin{array}{l}60.7 \\
39.3 \\
\end{array}$ & 150 & 7.099 & 3.89 \\
\hline
\end{tabular}

From the above table it is evident that most of the women working in different fields have a job experience between 1 to 5 years. When it comes to income the scale usually lies between 25000 to 35000 while working hours are from 6 to 8 as women had to take care of their families as well.

\subsection{Frequency Distribution and Percentage Analysis}

The frequency distributions of the few responses are given below:

Table 3: Frequency and Percentage analysis of Respondents (working women)

\begin{tabular}{|c|c|c|}
\hline Statement & No. of respondents & Percentage $\%$ \\
\hline $\begin{array}{l}\text { What is your professional level? } \\
\text { Employee } \\
\text { Manager } \\
\text { Director } \\
\text { Business owner } \\
\text { Other }\end{array}$ & $\begin{array}{c}. \\
1 \\
10 \\
41\end{array}$ & $\begin{array}{l}0.7 \\
6.6 \\
27.2\end{array}$ \\
\hline TOTAL & 151 & - \\
\hline $\begin{array}{l}\text { As far as your salaries and incentives are concerned are you? } \\
\text { Satisfied } \\
\text { Not satisfied }\end{array}$ & $\begin{array}{l}82 \\
66 \\
\end{array}$ & $\begin{array}{l}55.4 \\
44.6 \\
\end{array}$ \\
\hline TOTAL & 148 & 100 \\
\hline $\begin{array}{l}\text { by your job? } \\
\text { Nes }\end{array}$ & $\begin{array}{l}61 \\
70\end{array}$ & $\begin{array}{l}46.6 \\
53.4\end{array}$ \\
\hline TOTAL & 131 & 100 \\
\hline $\begin{array}{l}\text { Do you think that the status of working women is better than non-working } \\
\text { women in our society? } \\
\text { Yes } \\
\text { No } \\
\text { Don't know }\end{array}$ & $\begin{array}{l}81 \\
39 \\
29\end{array}$ & $\begin{array}{l}54.4 \\
26.2 \\
19.5\end{array}$ \\
\hline TOTAL & 149 & 100 \\
\hline
\end{tabular}


From the above observations it is quite evident that most of the working women are employed in different sectors and are satisfied with their salaries and incentives. But when it comes to shift duty more than $62 \%$ women are uncomfortable to fulfill their duty due to the main reason of transport and family. In this world of rapid growth and high demand to keep up with the world the women of Lahore also believes that the status of working women is far better and are not of the view to leave the jobs even if they had a chance.

\subsection{Hypothesis Development and Analysis}

Some hypothesis were applied to a few questions from our survey and verified by estimation techniques in statistics. A common interval for? that is $95 \%$ was used. Here is the list of hypotheses:

Table 4: Hypothesis development of Respondents (working women)

\begin{tabular}{|c|c|}
\hline $\mathrm{H}_{0 \mathrm{~A}}:$ & About $49 \%$ of the populations of working women in the survey are teachers. \\
\hline $\mathrm{H}_{1 \mathrm{~A}}:$ & Less than $49 \%$ of the populations of working women in the survey are teachers. \\
\hline $\mathrm{H}_{0 \mathrm{~B}}$ : & Equal to $60 \%$ of the population of working women has chosen a particular field due comfortable timings. \\
\hline $\mathrm{H}_{1 \mathrm{~B}}$ : & Less than $60 \%$ of the population of working women has chosen a particular field due comfortable timings. \\
\hline $\mathrm{H}_{0 \mathrm{C}}$ : & $\begin{array}{l}\text { Less than or equal to } 40 \% \text { of the women think it is not difficult for them to look after their } \\
\text { family/children. }\end{array}$ \\
\hline H1c: & More than $40 \%$ of the women think it is not difficult for them to look after their family/children. \\
\hline $\mathrm{H}_{0 \mathrm{D}}$ : & Half of the working women are of the view that low promotion of women is due to their work experience. \\
\hline $\mathrm{H}_{1 \mathrm{D}}:$ & $\begin{array}{l}\text { Less than half of the working women are of the view that low promotion of women is due to their work } \\
\text { experience. }\end{array}$ \\
\hline $\mathrm{H}_{0 \mathrm{E}}:$ & $\begin{array}{l}\text { Greater than and equal to } 50 \% \text { of the women believe that the most common problem faced is managing } \\
\text { job and household chores. }\end{array}$ \\
\hline $\mathrm{H}_{1 \mathrm{E}}:$ & $\begin{array}{l}\text { Less than } 50 \% \text { of the women believe that the most common problem faced is managing job and } \\
\text { household chores. }\end{array}$ \\
\hline $\mathrm{H}_{0 \mathrm{~F}}:$ & About $40 \%$ of the working women think that the most common health issue among them is mood swings. \\
\hline $\mathrm{H}_{1 \mathrm{~F}}:$ & $\begin{array}{l}\text { Less than } 40 \% \text { of the working women think that the most common health issue among them is mood } \\
\text { swings. }\end{array}$ \\
\hline
\end{tabular}


Table 5: Hypothesis Analysis of Respondents (working women)

\begin{tabular}{|c|c|c|c|c|}
\hline Hypothesis & p-Interval & p-value & Z-cal & Results \\
\hline $\begin{array}{l}\mathrm{H}_{0 \mathrm{~A}} \text { : About } 49 \% \text { of the populations of working } \\
\text { women in the survey are teachers. } \\
\mathrm{H}_{1 \mathrm{~A}} \text { : Less than } 49 \% \text { of the populations of working } \\
\text { women in the survey are teachers. }\end{array}$ & $\cdots$ & 0.49 & -1.975 & $\mathrm{H}_{1 \mathrm{~A}}$ \\
\hline $\begin{array}{l}\mathrm{H}_{0 \mathrm{~B}} \text { : Equal to } 60 \% \text { of the population of working } \\
\text { women has chosen a particular field due } \\
\text { comfortable timings. } \\
\mathrm{H}_{1 \mathrm{~B}} \text { : Less than } 60 \% \text { of the population of working } \\
\text { women has chosen a particular field due } \\
\text { comfortable timings. }\end{array}$ & $0.412-0.578$ & 0.60 & . & $\mathrm{H}_{1 \mathrm{~B}}$ \\
\hline $\begin{array}{l}\mathrm{H}_{0 \mathrm{C}} \text { : Less than or equal to } 40 \% \text { of the women think } \\
\text { it is not difficult for them to look after their } \\
\text { family/children. } \\
\mathrm{H}_{1 \mathrm{C}} \text { : More than } 40 \% \text { of the women think it is not } \\
\text { difficult for them to look after their family/children. }\end{array}$ & $0.28-0.43$ & 0.40 & -1.175 & $\mathrm{H}_{0 \mathrm{C}}$ \\
\hline $\begin{array}{l}\mathrm{H}_{0 \mathrm{D}} \text { : Half of the working women are of the view } \\
\text { that low promotion of women is due to their work } \\
\text { experience. } \\
\mathrm{H}_{1 \mathrm{D}} \text { : Less than half of the working women are of the } \\
\text { view that low promotion of women is due to their } \\
\text { work experience. }\end{array}$ & ... & 0.50 & -1 & $\mathrm{H}_{1 \mathrm{D}}$ \\
\hline $\begin{array}{l}\mathrm{H}_{0 \mathrm{E}} \text { : Greater than and equal to } 50 \% \text { of the women } \\
\text { believe that the most common problem faced is } \\
\text { managing job and household chores. } \\
\mathrm{H}_{1 \mathrm{E}} \text { : Less than } 50 \% \text { of the women believe that the } \\
\text { most common problem faced is managing job and } \\
\text { household chores. }\end{array}$ & $0.48-0.64$ & 0.50 & 1.5 & $\mathrm{H}_{0 \mathrm{E}}$ \\
\hline $\begin{array}{l}\mathrm{H}_{0 \mathrm{~F}} \text { : About } 40 \% \text { of the working women think that } \\
\text { the most common health issue among them is mood } \\
\text { swings. } \\
\mathrm{H}_{1 \mathrm{~F}} \text { : Less than } 40 \% \text { of the working women think } \\
\text { that the most common health issue among them is } \\
\text { mood swings. }\end{array}$ & $0.32-0.45$ & 0.40 & -1.5 & $\mathrm{H}_{0 \mathrm{~F}}$ \\
\hline
\end{tabular}

E. Survey Results[10]

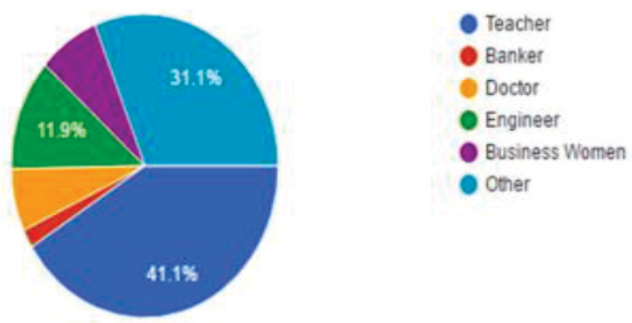

Fig 1: Which profession do you belong to?

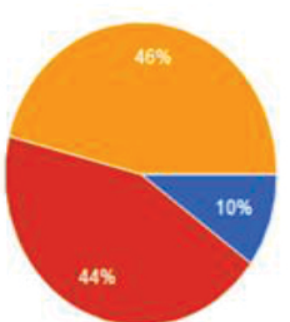

Fig 4: What are the causes of low promotion when it comes | to women in any organization as compared to men? 

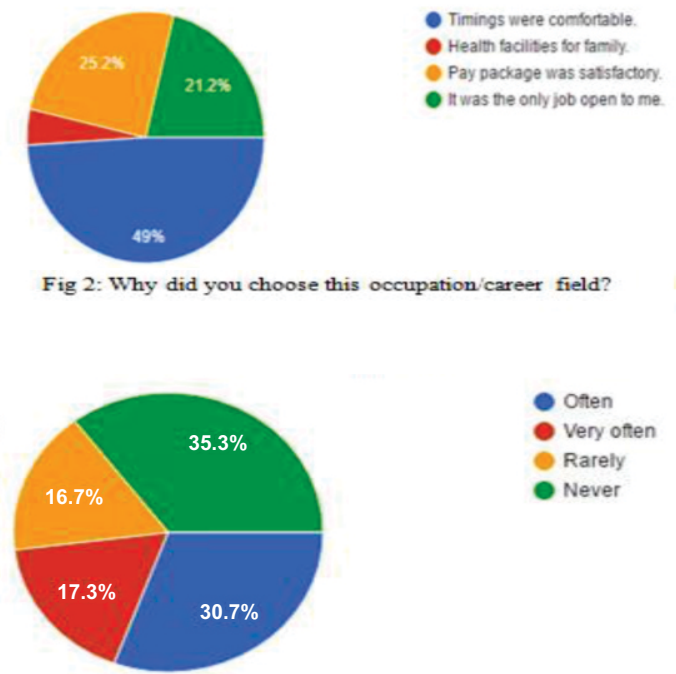

Fig 3: Do you find it difficult to look after your family members/children because of your work?

\section{CONCLUSION}

The survey in our study was able to identify the factors that affected the female employees' "work-life balance". We found that the stress connected with work and their responsibility towards their families was very significant determinant, together with their occupations, age. Managing between their responsibilities towards not only the families but towards the organization was also one of the pivoting reasons. Endless effort to maintain a balance between a person's work and family can have grave concerns on the life of an individual. It can seriously distress their welfare, health, comfort and general quality of life. There is an extensive need to balance work and domestic life in today's busy world where finding time for oneself is a luxury which seem like impossible. Government needs to provide health and wellness programs in order to provide a means to working women to bring about equilibrium in their private and professional life. [1] Both private and public sector have to change their strategies for women to have a balance between their family and life. [7] Proprietors now appreciate that resolving these problems would; therefore, benefit their personnel and increase throughput. [8] It is brilliantly said: "When women move forward the family moves, the village moves and the nation moves". Society is bound to take serious initiatives to produce a society in which there should be no "gender

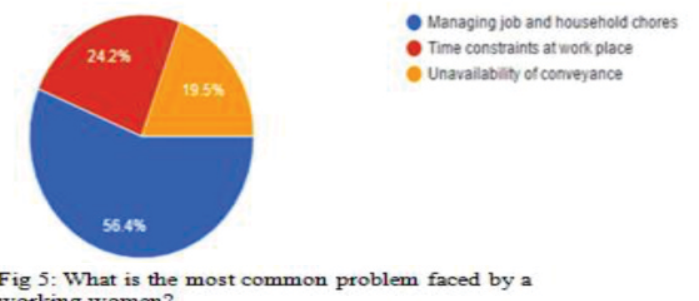

working women?
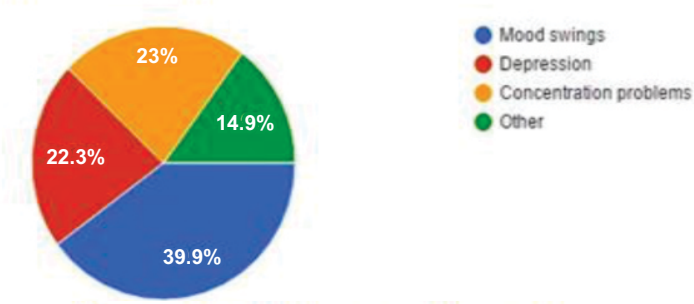

Fig 6: What kind of health issues did you face due to problems at workplace?

discrimination and women have complete authority of decision making and contributing in social, political and economic life of the country with a sense of impartiality." [9]

\subsection{Recommendations}

Based on the conclusions of the present study, subsequent commendations are put forward:

- Organization should make a promising atmosphere and better management strategies for females so that they can; without problems progress in their executive careers and organization can also take welfare of the diversity.

- Female executives should also deliver counseling and role modeling to their subordinate female contemporaries so that they can make improvement in their occupations.

- Government should also play its character by assembly new as well as imposing present laws to make working atmosphere harmless and reassuring for females.

- Media can play an optimistic role by administrating awareness movements and enlightening the culture about gender subjects.

- Civil societies and non-government establishments should also be involved in promoting as well as increasing awareness platforms for the multitudes. 


\section{References}

[1] G.Delina, Dr. R. Prabhakara Raya, "A study on Work-Life Balance in Working Women", 2011.

[2] Muhammad Abdullah Avais, Aijaz Ali Wassan, Saeedah Shah, "A Case Study on Problems of Working Women in City Sukkur", 2012.

[3] Huagui Zhu, Hafiz Ghufran Ali Khan and Muhammad Ilyas, "Challenges and risks faced by the working women in government organizations: An insight from Asian countries", 2012

[4] Jahan, R., "Women in Bangladesh", (1975).

[5] Getzel, J.W., \& Guba, E.G., "Role, conflict and Effectiveness", American Sociological Review, 164-175, 1954.

[6] Women \& Economy, 4th Roundtable ( $\mathrm{S}$ G G I ) $\mathrm{H}$ y d e $\mathrm{r} \quad\left(\begin{array}{llll}2 & 0 & 0 & 9\end{array}\right)$. https://www.ips.org.pk/difficulties-faced-byworking-women/

[7] Dr. (Smt.) Rajeshwari M. Shettar, Shri. Hurakadli Ajja Shikshan Samiti's Smt. K. S. and Dr. (Smt.) S. M. Sheshgiri DHARWAD-8, "A
Study on Issues and Challenges of Women Empowerment in India",

[8] Mr. G.Shiva Assistant "A Study on Work Family Balance and Challenges Faced By Working Women",

[9] Professional Women: The Continuing Struggle for Acceptance and Equality. Pearl Jacobs Sacred Heart University jacobsp@sacredheart.edu, Linda Schain HofstraUniversity actljs@hofstra.edu.

[10] Problems Faced by Working Women,

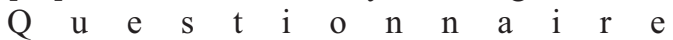
https://docs.google.com/forms/d/1MUcBQXO Y3mnBH3QYTeAa9jsXy98NJ7uu_KdFSnRK 04w/edit 